\title{
VLOGA EKOLOŠKEGA KMETOVANJA NA ZAVAROVANIH OBMOČJIH SLOVENIJE*
}

\author{
Matej Blatnik*, Matjaž Dovečar** \\ Oddelek za geografijo, Filozofska fakulteta Univerze v Ljubljani, \\ Aškerčeva 2, SI-1000 Ljubljana. \\ *e-mail: matejblatnik@gmail.com; *"e-mail: matjaz.dovecar@gmail.com
}

Pregledni znanstveni članek

COBISS 1.02

\section{Izvleček}

Zavarovana območja so znana po številnih posebnostih, bodisi naravnih, bodisi kulturnih, vendar zavarovanje prinaša določene omejitve, zaradi katerih se tudi kmetijstvo vse bolj usmerja v ekološko kmetovanje. Prispevek je povezan z raziskavo o ekološkem kmetovanju, njegovo uspešnostjo in njegovi pomembni vlogi v zavarovanih območjih. Kot primer so izbrana tri zavarovana območja v Sloveniji: Triglavski narodni park (TNP), Kozjanski regijski park (KRP) in Krajinski park Goričko (KPG). Rezultati so bili pridobljeni z intervjuji odgovornih za razvoj tamkajšnjega kmetijstva.

Ključne besede: ekološko kmetovanje, trajnostni razvoj, zavarovana območja, Triglavski narodni park, Kozjanski regijski park, Krajinski park Goričko

\section{ROLE OF ORGANIC FARMING IN SLOVENIAN PROTECTED AREAS}

\begin{abstract}
Protected areas are known for their cultural heritage and/or their natural landmarks, but the protection brings some special measures, which often represent obstacles for development of those areas. Agriculture is also a part of those protective measures and it is increasingly transformed into organic farming. This paper is based on organic farming research, it's development and its role in protected areas. For this purpose, we have chosen three importaint protected areas in Slovenia: Triglav National Park (TNP), Kozjansko Regional Park (KRP) and Goričko Landscape Park (KPG). Results were gathered by interviewing people, responsible for development of agriculture in those protected areas.
\end{abstract}

Key words: organic farming, sustainable development, protected areas, Triglav National park, Kozjansko Regional park, Goričko Landscape park 


\section{UVOD}

Ekološko pridelovanje hrane ima zaradi posebnega načina pridelave svojstvene značilnosti. V raziskovalni nalogi, katere poudarek je bil na potrošnji ekološko pridelane hrane, nas je zanimalo predvsem ekološko kmetovanje v luči trajnostnega razvoja in lokalne oskrbe s hrano, tržne poti, značilnosti in pričakovanja pridelovalcev ter potrošnikov ekološko pridelane hrane. Del našega raziskovalnega dela je bilo tudi preučevanje vloge ekološkega kmetovanja v zavarovanih območjih Slovenije in ugotoviti, ali mehanizmi za spodbujanje ekološkega kmetovanja tam obstajajo in če, kakšni so.

Za ekološko pridelano hrano je značilno, da je pridelana brez pesticidov in hitro topnih mineralnih gnojil. Dovoljena je uporaba organskih gnojil (npr. hlevski gnoj) in naravnih rudninskih gnojil (npr. kamena moka). Tako pridelana hrana je praviloma dražja od konvencionalno pridelane, a se pri vse večji težnji po zdravem življenju in okoljski ozaveščenosti ljudi pričakuje še hitrejši razvoj ekološkega kmetovanja in potrošnje ekološko pridelane hrane. Potrošniki ekološko pridelane hrane namreč cenijo zdravo hrano, pomembno pa jim je tudi varovanje okolja, skrb za dobro počutje vzrejanih živali in ohranjanje biotske raznovrstnosti.

Naše osnovno izhodišče pri raziskavi sta bila dva vidika ekološke pridelave:

- ekološki (ohranjanje biotske raznovrstnosti);

- socialno-ekonomski (pridelovanje zdrave hrane in zaposlitev oziroma dohodek).

Večina lastnosti in prioritet ekološke pridelave hrane gre ' $\mathrm{z}$ roko v roki' s cilji in prioritetami zavarovanih območij. Zaradi tega bi moralo ekološko kmetovanje znotraj teh območij predstavljati močno razvojno spodbudo, kar je bila tudi naša delovna hipoteza pred izvajanjem raziskovalnega projekta.

\section{ZAVAROVANA OBMOČJA V SLOVENIJI}

Za vsa zavarovana območja je značilna pestra naravna in družbena dediščina, ki so jo zaradi njihove vrednosti in ranljivosti predvsem lokalni prebivalci želeli zaščititi z raznimi ukrepi. Gre za oblikovanje posebnih prostorskih načrtov in primerne zakonodaje s sistemom nadzora (MOP 2008). Zavarovana območja nimajo le svoje načelne vrednosti, pač pa tudi velik ekonomski, ekološki in socialni potencial. Ta potencial je ključen za regionalni in tudi državni trajnostni razvoj, kljub temu pa varovanje pogosto predstavlja oviro razvoju zavarovanega območja. V Sloveniji imajo zavarovana območja velik potencial razvoja, še zlasti na področjih raziskovanja, izobraževanja, rekreacije, turizma in kmetijstva (Lampič in Mrak 2008).

Po podatkih Ministrstva za okolje in prostor (MOP) iz leta 2008 imamo v Sloveniji 48 širših zavarovanih območij oziroma naravnih parkov. Zavarovana območja, ki jih delimo na narodne (1), regijske (3) in krajinske parke (44), obsegajo dobro desetino države. Med njimi je z 83.807 ha površine največji Triglavski narodni park, večja sklenjena zavarovana območja pa so še Krajinski park Goričko, Regijski park Kozjansko, Krajinski park Ljubljansko barje in Notranjski regijski park. Poleg obstoječih sta v ustanavljanju še Regijski park KamniškoSavinjske Alpe in Krajinski park Radensko polje. V Sloveniji obstajajo tudi manjša zavaro- 
vana območja, ki jih delimo na naravne rezervate (52) in naravne spomenike (1217) (MOP 2008). V našem raziskovalnemu projektu smo podobneje preučili tri zavarovana območja: Triglavski narodni park (TNP), Kozjanski regijski park (KRP) in Krajinski park Goričko (KPG). Ta območja smo izbrali zaradi njihove poseljenosti, prisotnosti kmetijstva kot pomembnega dejavnika razvoja in oblikovalca kulturne pokrajine ter oblikovanja kulturne pokrajine.

- Triglavski narodni park (TNP) je naš edini narodni park. Ideja o varovanju ranljivega okolja se je uresničila leta 1924 v obliki zakupne pogodbe na območju Doline sedmerih jezer, leta 1961 pa postane narodni park. Zakon o Triglavskem narodnem parku v današnji obliki so nato sprejeli leta 1981. Narodni park se nahaja na severozahodu države. Večina ljudi ga ozemeljsko površno enači z Julijskimi Alpami, kar ne velja v celoti. Zanj je značilno tipično alpsko okolje, ki je predvsem geomorfološko in biotsko zelo pestro, a hkrati zelo občutljivo. $Z$ vidika kmetijstva sta na tem območju zelo pomembna razčlenjen in strm relief ter občutljivost naravnega okolja, ki sta razlog tudi za druge omejitve pri posegih v prostor in redko poselitev. V celotnem narodnem parku namreč danes živi le okoli 2200 ljudi (MOP 2008).

- Krajinski park Goričko (KPG), ki je bil ustanovljen leta 2003, se nahaja na skrajnem severovzhodu države, zavarovano območje pa se razprostira tudi v sosednjo Avstrijo in Madžarsko. Na zavarovanem območju živi okoli 20.000 ljudi, ki so že od nekdaj zelo navezani na lokalno okolje, za katero je značilna zelo raznolika raba tal. Na kmetijstvo pomembno vpliva celinsko podnebje z okoli $800 \mathrm{~mm}$ padavinami letno. Gre za območje, kjer pade daleč najmanj padavin v Sloveniji, kar pa je vsekakor naravna omejitev (MOP 2008).

- Kozjanski regijski park (KRP) obsega večji del širše pokrajine Kozjansko. Nahaja se južno od Voglajne, severno od vzhodnega Posavskega hribovja, vzhodno od Savinje. Status regijskega parka je območje dobilo leta 1999. Gre za zelo pestro in razgibano območje, kjer živi okoli 11.000 prebivalcev. V rabi tal prevladujejo gozdovi s $55 \%$ in kmetijske površine, predvsem njive, travniki, sadovnjaki in vinogradi, z okoli 45 \% (MOP 2008).

Zavarovana območja naj bi predstavljala zgled trajnostnega razvoja družbe. Ne gre torej le za varstvo okolja, pač pa za celoten proces ohranjanja kvalitetnega bivanja lokalnega prebivalstva v sožitju z naravo. Zaradi tega je pomembna sestavina zavarovanih območjih tudi ekološko kmetovanje, ki ima pomemben okoljski in razvojni potencial (MOP 2008).

\section{METODE DELA}

Eden od ciljev raziskovalnega dela je bil tudi ugotoviti sedanje značilnosti in perspektive razvoja ekološkega kmetovanja v izbranih zavarovanih območjih. Za dosego tega cilja smo si izbrali metodo intervjuja. Obrnili smo se na odgovorne za razvoj kmetijstva v izbranih območjih in sicer na gospoda Davorina Korena (odgovoren za področje kmetijstva v TNP), na gospo Stanko Dešnik (visoka naravovarstvena svetnica v Krajinskem parku Goričko) in gospoda Mitjo Zupančiča (odgovoren za ekološko kmetijstvo v Savinjski regiji). 
$Z$ vodenim intervjujem smo želeli izvedeti informacije o naslednjih tematikah:

- stališče odgovornih do ekološkega kmetovanja: (ne)naklonjenost razvoju ekološkega kmetovanja in morebitno promoviranje;

- število ekoloških pridelovalcev v posameznih območjih in njihova usmerjenost: kaj pridelujejo in kaj predelujejo;

- uveljavljanje ekoloških pridelovalcev na trgu: poznanost, dober glas, medsebojno povezovanje in sodelovanje;

- vloga upravljalcev in njihova pomoč ekološkim pridelovalcem;

- prednosti in slabosti ekološkega kmetijstva;

- perspektiva ekološkega kmetijstva v zavarovanih območjih.

Slika 1: Preučevana zavarovana območja in lokacije ekoloških kmetij

Figure 1: Studied protected areas and locations of organic farms

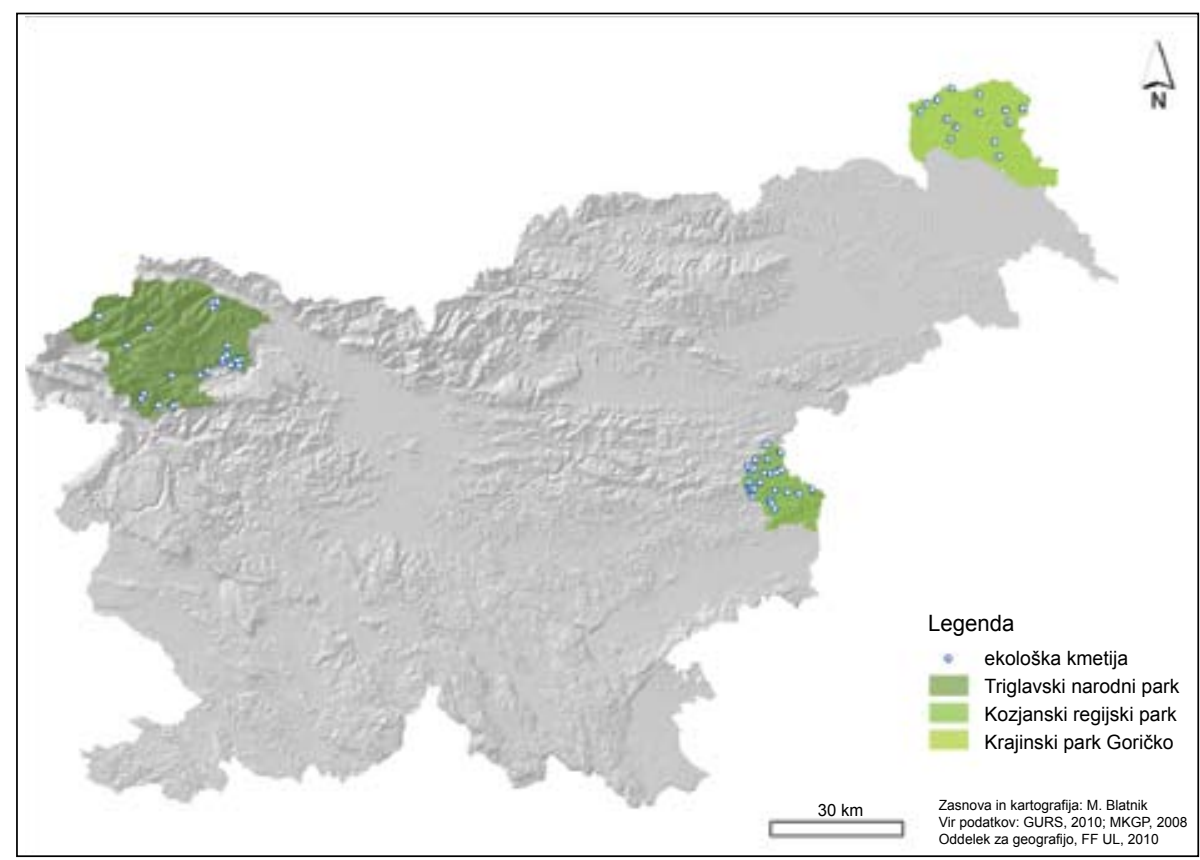

\section{ZNAČILNOSTI EKOLOŠKEGA KMETOVANJA V ZAVAROVANIH OBMOČJIH IN NJEGOV POTENCIAL}

Zanimal nas je odnos upravljalca zavarovanega območja do ekološkega kmetovanja. Taka oblika kmetovanja ima namreč manjše obremenilne vplive na okolje. Kmetovalci TNP z zakonodajo in pravilniki niso obvezani k preusmeritvam (na ekološko kmetovanje), jih pa 
uprava zavarovanega območja k temu spodbuja na različne načine. Uprava TNP je bila zelo zadovoljna z uvedbo kmetijsko-okoljskih programov (t.i. SKOP), saj so ljudje znotraj parka prejemali za 20 \% višje subvencije pri ekološki pridelavi hrane. Prav tako ekološko kmetovanje omejujejo naravnogeografske značilnosti, natančneje nadmorska višina in nakloni pobočij, saj kmetovalci iz TNP s količino pridelka praviloma ne morejo konkurirati na trgu. Tudi ob morebitnem združenju ekoloških kmetovalcev bi bili tržni viški majhni. Investiranje v hitrejši razvoj kmetijstva se tu, po mnenju Davorina Korena, ne bi izplačalo.

Tudi v Krajinskem parku Goričko imajo glede ekološkega kmetovanja pozitivno stališče. Poleg varovanja narave želijo lokalnim kmetovalcem in prebivalcem zagotoviti nadaljnji obstoj v kvalitetnem okolju. Ekološko kmetovanje ima na območju parka zaradi posestne razdrobljenosti zelo dobre pogoje za razvoj. Kljub temu se, predvsem zaradi nezainteresiranosti ter neugodne izobrazbene in starostne strukture prebivalcev, ekološko kmetovanje le počasi razvija.

V Kozjanskem regijskem parku vidijo v ekološkem kmetovanju le prednosti. Pozitivni vidik te dejavnosti je predvsem ohranjanje naravne pokrajine. Park močno podpira ekološke kmetovalce, hkrati pa se zavedajo, da se z vsemi omejitvami marsikdo ne strinja.

Pomembna informacija je tudi število ekoloških pridelovalcev v zavarovanih območjih in njihov pričakovan trend. Anketiranje potrošnikov ekološko pridelane hrane v nakupovalnih središčih in na ekoloških tržnicah je pokazalo, da tretjina vseh vsaj nekajkrat letno nakupuje ekološka živila na kmetijah samih. Zaradi učinkovite lokalne oskrbe z ekološko pridelano hrano je zelo pomembno število ekoloških kmetij in njihova prostorska razporeditev.

Po podatkih MKGP za leto 2008 je v izbranih zavarovanih območjih 70 ekoloških kmetij (s sedežem znotraj zavarovanega območja). Pri tem je treba upoštevati še dejstvo, da so v izbranih območjih tudi zemljišča ekoloških kmetij, ki imajo prijavljen sedež izven zavarovanega območja. V TNP je prisotnih 30 ekoloških kmetij, njihovo število pa trenutno stagnira. Na to vplivajo predvsem subvencije, ki so vezane na površino, četudi je del posesti izven zavarovanega območja. Precejšnji problem kmetom predstavlja veliko dela z administrativnimi postopki, prav tako manjka povezovalni element med pridelavo in prodajo. Manjkajo zlasti investicije v predelovalne obrate in svetovanja lokalnim kmetovalcem. Tudi zaradi tega v prihodnje pričakujejo upad števila ekoloških kmetovalcev, kljub očitnemu velikemu interesu potrošnikov.

Na območju Krajinskega parka Goričko je prijavljenih 16 ekoloških kmetij. Prebivalci zavarovanega območja se zavedajo pomena lokalne kulinarike in ekološkega kmetovanja (Tiran in sod. 2008). Ekološke kmetije v Krajinskem parku Goričko so po površini manjše od tistih iz TNP oziroma Kozjanskega regijskega parka (MKGP 2008). Povprečna velikost ekološke kmetije v Krajinskem parku Goričko namreč znaša slabih 5 ha, medtem ko je povprečna ekološka kmetija v Kozjanskem regijskem parku velika 9,2 ha, v TNP pa 12,59 ha.

V Kozjanskem regijskem parku je prijavljenih 24 ekoloških kmetij. Ob tem upajo, da se bo njihovo število $\mathrm{v}$ prihodnosti povečevalo, saj so zadnja tri leta $\mathrm{v}$ to dejavnost vlagali veliko truda. Število ekoloških kmetij se ne povečuje, se pa na račun travniških povečujejo površine obdelovalnih površin z vrtninami in sadjem ter površine vinogradov. Pričakovani trend je torej pozitiven. 
Preglednica 1: Število ekoloških kmetij in skupna površina zemljišč na obravnavanih zavarovanih območjih

Table 1: The number of organic farms and their total area of land in the protected areas

\begin{tabular}{|l|c|c|}
\hline & Število ekoloških kmetij & Površina zemljišč v ha \\
\hline Triglavski narodni park (TNP) & 30 & 377,7 \\
\hline Kozjanski regijski park (KRP) & 24 & 221,9 \\
\hline Krajinski park Goričko (KPG) & 16 & 79,5 \\
\hline
\end{tabular}

Vir/Source: Ministrstvo za kmetijstvo, gozdarstvo in prehrano 2008

Zanimalo nas je tudi, kaj ekološki kmetje v zavarovanih območjih pridelujejo in kaj predelujejo. Pridelava je odvisna predvsem od naravnih pogojev za kmetovanje. Več pridelovalcev nekega izdelka pa ponuja možnost za medsebojno povezovanje, s tem pa tudi učinkovitejši nastop na trgu in možnost začetka predelave ekološkega živila $\mathrm{z}$ višjo dodano vrednostjo. Na območju TNP je najbolj prepoznavna ekološka izdelava sira, kjer sta najbolj značilna bohinjski sir in tolminc. Na območju Bohinja je problem v tem, da prihaja do premajhnih cenovnih razlik med ekološkimi in ne-ekološkimi izdelki, zaradi česar se veliko izdelkov proda kot ne-ekoloških.

V Krajinskem parku Goričko nimajo pestre ponudbe ekološko pridelane hrane. Najpomembnejša je ovčereja, ki velja za eno izmed najenostavnejših ekoloških dejavnosti. V bližnji okolici zavarovanega območja so prisotni tudi ekološki pridelovalci zelenjave, žit in prosta reja perutnine.

V Kozjanskem regijskem parku ima večina kmetovalcev zaradi razgibanega reliefa in majhnosti kmetij več različnih dejavnosti in s tem pester spekter ekološke pridelave in predelave.Pridelujejovečvrstžit(vzadnjemčasu spetstaražita:rž, proso, ajda)terzelenjavoin sadje, pri katerem so pomemben in prepoznaven znak celotnega območja stare sorte kozjanskih jabolk. Na gričevnatem svetu ima določeno vlogo vinska trta, ukvarjajo pa se tudi z živinorejo. Pri predelavi se ukvarjajo s peko kruha, peciva in izdelovanjem testenin, predelovanje sadja v marmelade, jabolčne sokove, kis in žganje ter sušenje sadja. Dodatno dejavnost predstavlja čebelarstvo, ena od ekoloških kmetij pa se ukvarja s turizmom.

Pomembno je tudi uveljavljanje ekoloških pridelovalcev na trgu. Potrošniki ekoloških živil namreč zelo cenijo 'dober glas' in mu pri nakupovanju dajejo velik pomen. Pridelovalci TNP so združeni v dve društvi ekoloških kmetovalcev, in sicer Gorenjske in Severne Primorske. S prodajo ekoloških pridelkov imajo na Gorenjskem veliko težav, zlasti pri mleku in mesu, saj je proizvodnja tako nizka, da imajo s trženjem več stroškov kot prihodkov.

$\mathrm{Na}$ Goričkem se pridelovalci do sedaj niso povezovali. V okviru podjetja Era Velenje so ustanovili nekoliko širšo koalicijo, ki je naredila konzorcij vseh kmetov v Pomurju (tudi štajerskih in prleških). Večino izdelkov se proda na domu, ostalo pa občasno na ekološki tržnici v Murski Soboti, ki formalno še ne obstaja. V bližnji okolici je veliko dela pri povezovanju opravil ekološki center Svit, ki med drugim skrbi za prodajo njihovih izdelkov (povezava s trgovino Kalček Ljubljana in Sončnica Murska Sobota).

Med ekološkimi kmeti znotraj Kozjanskega regijskega parka ni posebnega sodelovanja. Posamezni kmeti se povezujejo v društvo Deteljica, ki je povezava ekoloških pridelovalcev 
širše celjske regije. Biodar je zveza ekoloških kmetov Slovenije, pod katero se tržijo tudi ekološki pridelovalci iz Regijskega parka Kozjansko. Velik razvojni potencial območja vidijo v povezovanju ekoloških pridelovalcev s t.i. javnimi kuhinjami (npr. v šolah). Kmetovalci bi tako imeli redne odjemalce, javne kuhinje pa bi bile preskrbljene z lokalno in zdravo pridelano hrano.

Zanimal nas je tudi način pomoči pridelovalcem s strani upravljalcev zavarovanih območij - ali je pomoč bolj izobraževalne narave, ali gre za pomoč pri pridobitvi finančnih spodbud ipd. TNP se trudi zagotoviti izobraževalno in finančno pomoč. Pri slednji gre za program razvoja tradicionalnih načinov pridelave, preusmeritev kmetij v ekološke, sanacije hlevov ipd. Kmetovalci so bili tu deležni raznih oblik pomoči, še preden se je oblikovala zakonodaja o ekološkem kmetovanju v Sloveniji. Takrat so namreč s sodelovanjem avstrijskih strokovnjakov organizirali predavanja za kmete in ustvarili načrt oblikovanja jeder ekološkega kmetovanja (primera Čadrg in Log pod Mangartom). Pomoči v obliki izobraževanja naj bi bilo v Sloveniji premalo, saj ekološki kmetovalci pogosto ne razumejo namena in upravičenosti do subvencij in spodbud, zakaj morajo izpolnjevati administrativne papirje ipd.

Pomoč ekološkim kmetovalcem nudijo tudi na Goričkem. Pred dvema letoma so namreč skupaj z narodnim parkom Örség na Madžarskem prijavili projekt, v okviru katerega so priskrbeli opremo za malo pilotsko sirarno, ki bo postavljena v Ratkovcih. Namen je pritegniti kmete, da bi redili drobnico in krave za mleko in ga predelovali v tej sirarni. V projektu so bili zajeti vidiki izobraževanja, financiranja, promocije, trženja ter prodaje. Nakupili so tudi hladilne vitrine, ki so jih podarili pomurskim trgovinam z lokalnimi ekološkimi izdelki.

V Kozjanskem regijskem parku pomagajo ekološkim kmetovalcem na različne načine. Pri usmerjanju in pomoči prestrukturiranja v ekološko kmetijstvo pomagata društvo Deteljica in KGZ Celje. Pod okriljem parka je nastalo društvo Kozjanske jabke, da bi spodbujali ohranjanje starih sort jablan in hrušk in stari način predelave. Pomembna skrb društva je tudi vzpodbujanje ekološke pridelave sadja in izdelava naravi prijaznih proizvodov, izvajajo promocijske aktivnosti, sodelujejo z lokalnimi skupnostmi in sodelujejo na sejmih. V povezavi s travniškimi sadovnjaki in naravnim kmetovanjem pa v parku izvajajo še zanimiv projekt ohranjanja solitarnih (divjih) čebel. Uprava parka je s pridobivanjem evropskih sredstev in sredstev občine pripomogla tudi pri projektu gradnje rastlinske čistilne naprave pri tamkajšnjem kmetu.

Pozanimali smo se tudi o prednostih in slabostih ekološkega pridelovanja v zavarovanih območjih. Strokovnjaki s področja kmetovanja vidijo v ekološki pridelavi večinoma le prednosti, zato smo se nekoliko bolj osredotočili na morebitne slabosti ali pomanjkljivosti. V TNP so kot negativno lastnost izpostavili izkoriščanje značilnosti ekološkega kmetovanja za zniževanje stroškov pridelave, npr. slabo ravnanje z živino na odprtem (da bi bile brez ustreznega zavetja, da bi bile podhranjene ipd.). Podobna napaka se je pripetila v Združenih državah Amerike. V zakonu o ekološki pridelavi mleka namreč ni pisalo, da morajo kmetovalci krave mlekarice na paši dejansko krmiti. Zdaj so ta zakon preoblikovali - krave mlekarice morajo vsaj 30 odstotkov hrane dobiti s paše (medmrežje 1). Pojavlja se tudi problem neustrezne usposobljenosti kontrolorjev.

Tudi na Goričkem vidijo v ekološkem kmetovanju le prednosti. Ekološko ozaveščeni kmetje imajo večji posluh za varstvo narave, saj so od nje zelo odvisni. Zavedajo se pomena 
trajnostnega načina obdelave in omejevanja uporabe umetnih gnojil ter sintetičnih zaščitnih sredstev, četudi to pomeni nekoliko manjšo količino pridelave. Slabosti v ekološkem kmetovanju ne vidijo.

Slika 2: Ekološka kmetija 'Pri Seljanu'v Čadrgu (foto: Š. Blatnik)

Figure 2: Organic farm 'Pri Seljanu' in Čadrg (photo: Š. Blatnik)

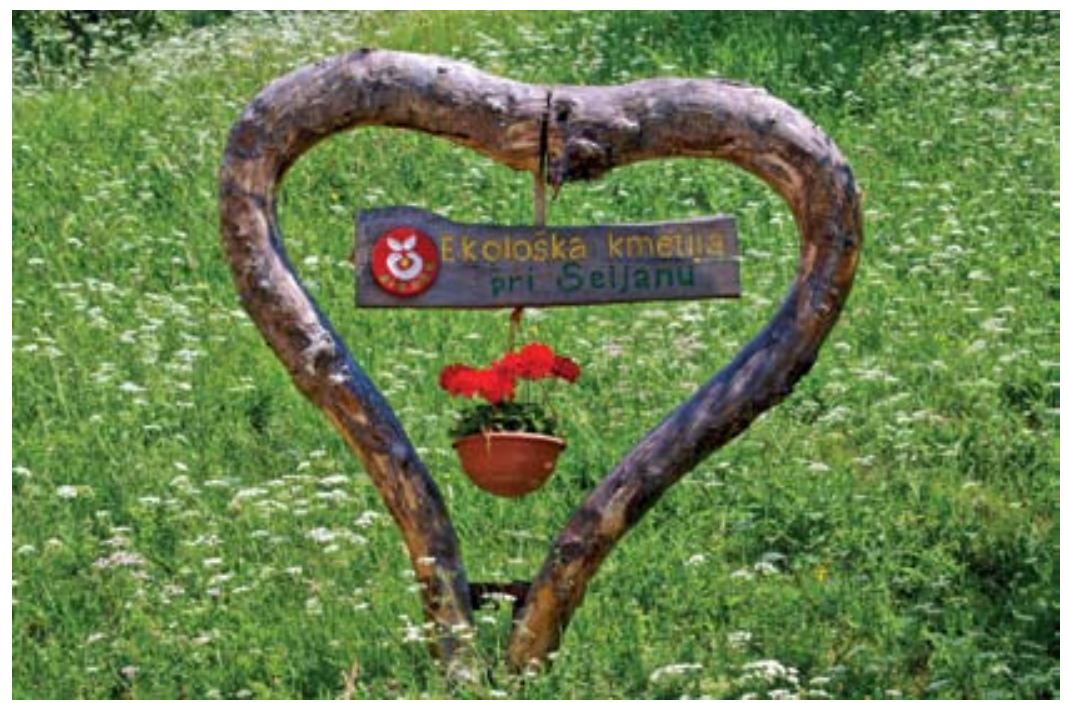

V Kozjanskem regijskem parku vidijo pomanjkljivosti zlasti pri pridelavi mesa - krma je dražja od ne-ekološke, meso pa je zaradi žilavosti pri potrošnikih manj cenjeno. Ekološki kmetovalci so tako velikokrat v izgubi, saj so njihovi stroški višji od zaslužka. Po besedah ekološkega pridelovalca Krivca iz Pokleka pri Podsredi, je ena izmed večjih prednosti Kozjanskega regijskega parka prav njegova obrobna lega. Lokacija, ki je oddaljena od večje industrije, strnjene poselitve in obremenjenih prometnic, nudi velik potencial. Kupci so bolj zaupljivi do izdelkov iz takšnih območij in bi jih pri potencialno večji ponudbi v prihodnje verjetno hitreje sprejeli.

V zavarovanih območjih organizirajo tudi izobraževanja za ekološke pridelovalce. Ta so še zlasti pomembna za učinkovit razvoj ekološkega kmetijstva in ekološke predelave. V TNP so izpostavili že prej omenjene SKOP programe, v okviru katerih morajo kmetje obvezno poročati o njihovi pridelavi, pri izpolnjevanju obrazcev pa jim uprava zavarovanega območja pomaga $\mathrm{z}$ nasveti.

Tudi na Goričkem in v Kozjanskem regijskem parku so tovrstna izobraževanja zelo zaželena. Na Kmetijsko gozdarskem zavodu (KGZ) so izobraževanja o biotski raznovrstnosti in ohranjanju narave že več let ustaljena praksa, a jih izvajajo le svetovalci kmetijskega zavo$\mathrm{da}$ in gostujoči predavatelji z mariborske univerze, ki naj bi bila v Sloveniji najbolj specializirana za ekološko kmetijstvo. 
Prihodnost ekološkega kmetovanja na območju Slovenije je po mnenju omenjenih strokovnjakov dobra, saj naj bi se stroški pri ekološkem kmetovanju (pogled zgolj na investicije, tekoče stroške in končne zaslužke) zmanjšali, hkrati pa naj bi se povečal delež ljudi, ki bi se ukvarjali z ekološkim kmetovanjem zaradi lastnega veselja. Prav tako se povečuje ozaveščenost ljudi in interes potrošnikov po ekološko pridelani hrani, saj že sedanja ponudba ne zadovoljuje celotnega povpraševanja, zaradi česar se veliko hrane uvozi s tujine. Opazili so tudi zanimiv proces, ki naj bi ga sprožila svetovna gospodarska recesija, da se živilsko-predelovalna industrija preusmerja v predelavo ekološko pridelane hrane (primer mlekarne Krepko Logatec). Po mnenju svetovalca za ekološko kmetijstvo Mitje Zupančiča mora ideja o ekološki pridelavi dozoreti pri vsakem posamezniku. Ekološko kmetovanje ima velik razvojni potencial, a večina ljudi še ne dojema vseh prednosti, ki jih prinaša. Izjema so ljudje, ki živijo znotraj ali v bližini zavarovanih območij. Ti so praviloma okoljsko bolj ozaveščeni od ostalih in bolj 'verjamejo' v ideje ekološkega kmetovanja. Pomembno se je namreč zgledovati po domačih in tujih primerih dobre prakse.

Slika 3: Ekološka tržnica na Bledu (foto: M. Blatnik, 2010)

Figure 3: Organic market in Bled (photo: M. Blatnik, 2010)

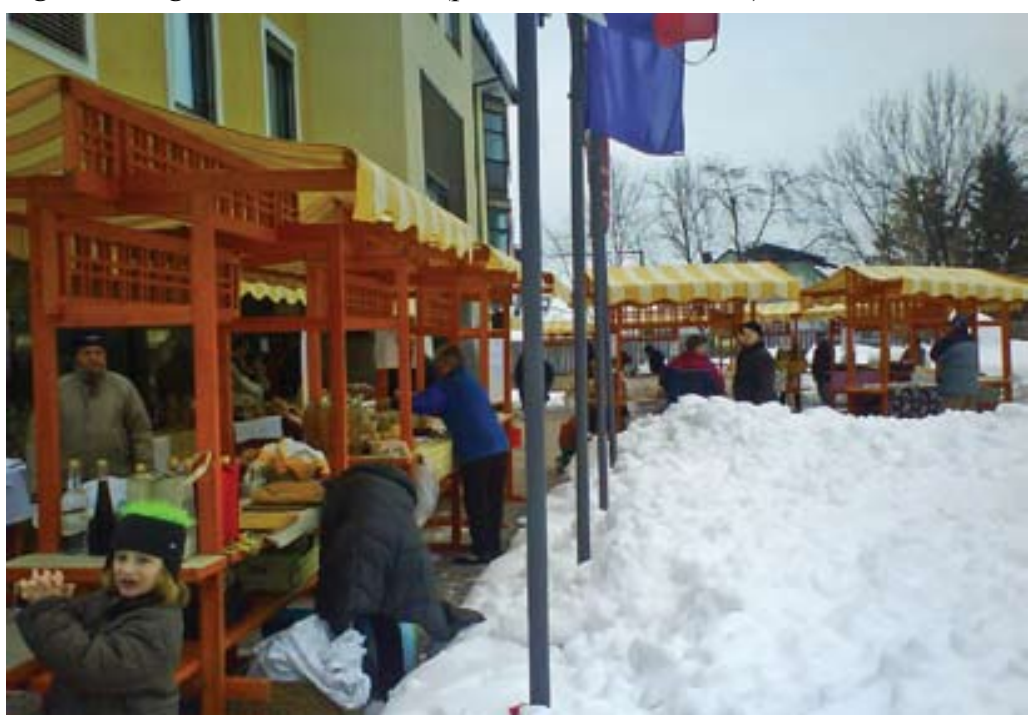

Pomemben podatek je tudi odnos prebivalcev in konvencionalnih kmetovalcev do ekološkega kmetovanja, ki je zelo pomemben za prihodnji razvoj ekološkega kmetovanja na nekem območju. Po informacijah Davorina Korena prebivalci TNP znajo ceniti naravno okolje ter kulturno dediščino in s tega vidika podpirajo ekološko kmetovanje. Nekoliko manj so zadovoljni $\mathrm{z}$ dolgotrajnimi in zapletenimi administrativnimi postopki. Konvencionalni kmetovalci ekološko kmetovanje povezujejo z različnimi stereotipi, npr. s podhranjenostjo ekoloških krav. Prav tako konvencionalni kmetovalci ne razumejo finančne smotrnosti pri ekološki krmi za prežvekovalce, ki naj bi bila zelo draga in mora biti uvožena. 
$\mathrm{Na}$ Goričkem imajo težave z motiviranjem mladih naslednikov na kmetijah, ki se pogosto odločijo za študij in kasnejšo zaposlitev daleč od domače okolice. Delovno silo zaenkrat pridobivajo prek javnih del, a to ni vedno racionalna in dolgoročna rešitev. Z ekološkim kmetovanjem se ohranja tradicionalna mešana raba pokrajine in onemogoča opuščanje ter zaraščanje površin. Konvencionalni kmetovalci se ne počutijo ogrožene in se ekološki pridelavi nekoliko posmehujejo. Po letu 2013 naj bi se zadeve na tem področju spremenile, saj bi kmetovalci lahko svojo dejavnost znotraj območja Natura 2000 začeli bolje izkoriščati. Kmetovalci, ki bodo skrbeli za ptice in čebele, bodo namreč upravičeni do določenih ugodnosti in nagrad.

Zavarovana območja nudijo ekološkim kmetovalcem številne ugodnosti in boljše pogoje za obstoj. Ena izmed njih je zagotovo promocija, ki vključuje prodajo njihovih ekoloških izdelkov. V TNP ta niša še ni povsem izkoriščena. Ekološke izdelke bi lahko, npr. z zaščitnim znakom parka, uspešneje tržili. Tak primer je narodni park Dolomiti Bellunesi, v katerem spodbujajo trajnostni razvoj v skladu z Agendo 21 (medmrežje 3). Ponudnikom ekološko pridelane hrane, turističnim ponudnikom in drugim ob izpolnjevanju določenih pogojev, podeljuje certifikate. S tem ukrepom si ustvarjajo 'dober glas', na trgu pa so (tako na domačem kot tudi na tujem) bolje prepoznani in cenjeni. V Sloveniji se takih ukrepov zaenkrat še ne poslužujemo. Posebnih ogledov ekoloških kmetij kot turistično zanimivost v TNP ne ponujajo, kljub temu pa je naselje Čadrg med turisti dobro poznano.

Na Goričkem promocija še ni povsem zaživela, si pa zelo prizadevajo za oživitev in posledično boljšo promocijo sirarne, vendar trenutno ni dovolj zanimanja. Turistov na ekološke kmetije ne vodijo, bodo pa v prihodnje zagotovili nastanitvene kapacitete.

V Kozjanskem regijskem parku je sodelovanje med kmeti in parkom bolj vzajemno. Ekološki kmetovalci na tržnicah ponujajo razne promocijske zloženke o parku, v katerem so turistom posredovane informacije o kmetijah in njihovih nastanitvah. Neizkoriščenih možnosti povezave turizma z ekološkimi kmetijami je še veliko. Tržili bi lahko npr. 'kozjansko jabko', ki je prepoznaven znak parka in je pridelana z vsemi standardi ekološke pridelave. Ker pa ni registrirana, se na tak način ne more promovirati.

Pri zadnjem vprašanju nas je zanimalo današnje in morebitno prihodnje spodbujanje ekološkega kmetovanja kot enega izmed možnih mehanizmov za ohranjanje kulturne pokrajine ter ohranjanje tradicionalnih kultur. V TNP se zavedajo, da bodo morali še veliko narediti na področju spodbujanja tovrstnega kmetovanja, ob tem pa so omenili tudi nov Zakon o Triglavskem narodnem parku, ki je stopil v veljavo 14. julija 2010 (medmrežje 2). Tudi s pomočjo tega zakona nameravajo ekološko kmetovanje močno spodbuditi, a ne finančno. To je namreč $\mathrm{v}$ domeni države in ne zavarovanega območja oziroma posamezne občine, vseeno pa podpirajo razne razvojne projekte (npr. Aktivnost človeka in varovanje narave). Hkrati pa se zavedajo pomanjkljivosti, da imajo v zavarovanem območju premalo zaposlenih na tem področju. Zaželen je večji poudarek na razvoju, učinkovitejši nadzor in višje sofinanciranje. Gospod Davorin Koren je namreč edini zaposleni v Triglavskem narodnem parku na področju kmetijstva (tako konvencionalnega, kot tudi ekološkega).

Tudi na Goričkem se trudijo na raznih področjih, tako je npr. uprava uredila okoli 13 ha zemljišč z ekološkimi sadovnjaki. Finančne pomoči ne morejo nuditi, trudijo pa se ljudi spodbuditi z izobraževanji in s praktično pomočjo (npr. pridobivanje evropskih sredstev). $\mathrm{Na}$ 
avstrijski strani meje so kmetovalci bolje povezani in organizirani, k čimer bodo težili tudi na slovenski strani.

V Kozjanskem regijskem parku so travniški sadovnjaki razpoznavna in nepogrešljiva sestavina podeželske kulturne pokrajine. S projektom 'Obnova starih travniških sadovnjakov' želijo ohraniti kulturno pokrajino $\mathrm{v}$ tradicionalni podobi. $\mathrm{V}$ okviru projekta so temeljni cilji: vzdrževanje sadovnjakov kot redkih ekoloških niš, ohranjanje starih sort za prihodnje, preprečevanje dezertifikacije ter vključevanje proizvajalcev in nastop na trgu pod skupno blagovno znamko 'Sožitje'.

\section{SKLEP}

Ekološko kmetijstvo predstavlja obliko in način kmetovanja, ki v Sloveniji postopoma pridobiva na pomenu. Naša država ima pestre naravne danosti z bogato pokrajinsko raznovrstnostjo ter $z$ velikim deležem gorsko-višinskih kmetij ter območij z omejenimi možnostmi za kmetijsko dejavnost. Poleg naravnih danosti ne smemo zanemariti bogat človeški kapital - ljudje so večinoma dobro izobraženi in okoljsko ozaveščeni. Hkrati ekološki kmetje pripomorejo k večji identiteti nekega (kmetijskega) območja.

Med 433 anketiranimi potrošniki po Sloveniji se je pokazalo, da jih kar 31 \% vsaj nekajkrat letno kupuje ekološko pridelana živila na ekoloških kmetijah samih. Iz tega in drugih rezultatov raziskovalnega dela sklepamo, da bi morali ekološki kmetje predstavljati pomemben vir lokalne oskrbe s hrano. Vendar pa slabo medsebojno povezovanje ekoloških pridelovalcev, slabo poznavanje zakonodaje in drugi (predvsem naravni) omejitveni dejavniki močno zavirajo razvoj ekološkega kmetovanja, ki ima po našem mnenju velik potencial še zlasti v zavarovanih območjih.

\section{Viri in literatura}

Blatnik, M., Dovečar, M. 2010: Značilnosti in pričakovanja potrošnikov ekološko pridelane hrane. Elaborat, Oddelek za geografijo, Filozofska fakulteta Univerze v Ljubljani. Ljubljana.

Lampič, B., Mrak, I. 2008: Vrednote, vrednosti in razvojni potenciali območij varovanja. Dela 29. Ljubljana.

Medmrežje 1: http://www.bodieko.si/strozja-pravila-za-ekolosko-pridelano-mleko-v-ameriki (citirano: 26. 08. 2010).

Medmrežje 2: http://www.tnp.mop.gov.si/ (citirano: 28. 08. 2010).

Medmrežje 3: http://www.dolomitipark.it/doc_pdf/life/MAT_Agemas_report_inglese.pdf (citirano: 28. 08. 2010).

Ministrstvo za kmetijstvo, gozdarstvo in prehrano (MKGP). Podatki o ekološkem kmetovanju v Sloveniji. Ljubljana 2008.

Ministrstvo za okolje in prostor (MOP). Zavarovana območja v Sloveniji. Ljubljana 2008.

Tiran, J., Kozina, J., Gostinčar, P., Pirjevec, E. 2008: Razvojni potenciali zavarovanih območij. Dela 29. Ljubljana. 


\section{ROLE OF ORGANIC FARMING IN SLOVENIAN PROTECTED AREAS}

\section{Summary}

This paper is based on our individual research project about organic farming. Part of this project was to find a connection between organic farming and protected areas in Slovenia. For this purpose, we used interview as our main scientific method. We focused our research on three (geographically diverse) protected areas: Triglav National Park, Nature Park Goričko and Regional Park Kozjansko.

Because of extensive use of natural resources people have encountered many ecological threats, especially in the last century. Now we realize the significance of so called sustainable development (development which also accounts for natural renewable capacity). Most of developed countries have incorporated basic ideas of sustainable development into their development and basic regional plans, especially in protected areas. Those areas were, because of natural and cultural heritage, already bound with special protective rules and laws. Majority of local population knows and agrees with restrictions, but there are still some, who don't. Conventional farmers, for instance, have many restrictions in usage of artificial fertilizers (composed out of nitrogen, phosphorus, and potassium). Therefore, we believe that organic farming is the only form of farming in protected areas, which can guarantee development, high quality of living, maintain rural settlements, contributes to higher local identity etc. Our research has shown that one third of ecological food consumers several times per year buys their groceries directly from organic farms at least once a year. Therefore, the production of organic food is important also for local food supply. Organic farming and goals of protected areas already well complement one another in many regions (for instance in many Alpine protected areas).

Slovenia's natural and cultural heritage is rich and diverse, but our efforts regarding organic farming should be stronger and measures better organized. We need more educated people to help farmers with their administrative tasks, connectors between organic production and organic processing, people who would improve advertising, marketing etc.

\footnotetext{
* Članek je nastal v okviru samostojnega raziskovalnega projekta "Značilnosti in pričakovanja potrošnikov ekološko pridelane hrane«, ki se je izvajal pri usmeritvenem predmetu Varstvo geografskega okolja v povezavi z delom Raziskovalnega centra Oddelka za geografijo Filozofske fakultete. Projekt je nastal pod mentorstvom dr. Metke Špes, doc. dr. Barbare Lampič in doc. dr. Irene Mrak, izvajalci projekta pa so bili študenti 4. letnika geografije: Matej Blatnik, Mirja Bobnar, Jasmina Čer, Matjaž Dovečar, Martina Flek, Jan Janžekovič, Teja Jerman, Nataša Kramar, Petra Mars, Tadeja Rataj in Gašper Šubelj.
} 